\title{
Impacts of experimentally imposed drought on leaf respiration and morphology in an Amazon rain forest
}

\author{
Daniel B. Metcalfe ${ }^{*, 1}$, Raquel Lobo-do-Vale ${ }^{2}$, Manuela M. Chaves ${ }^{2}$, Joao P. Maroco ${ }^{3,4}$, \\ Luiz E. O. C Aragão ${ }^{1}$, Yadvinder Malhi ${ }^{1}$, Antonio L. Da Costa ${ }^{5}$, Alan P. Braga ${ }^{5}$, \\ Paulo L. Gonçalves ${ }^{5}$, Joao De Athaydes ${ }^{5}$, Mauricio Da Costa ${ }^{5}$, Samuel S. Almeida ${ }^{6}$, \\ Catherine Campbell ${ }^{7}$, Vaughan Hurry ${ }^{7}$, Mathew Williams ${ }^{8}$ and Patrick Meir ${ }^{8}$ \\ ${ }^{1}$ Environmental Change Institute, University of Oxford, Oxford OX1 3QY, UK; ${ }^{2}$ Instituto Superior de Agronomia, \\ Universidade Tecnica de Lisboa, Lisbon 1349 017, Portugal; ${ }^{3}$ Instituto Superior de Psicologia Aplicada, Lisbon 1149041, \\ Portugal; ${ }^{4}$ Instituto de Tecnologia Quimica e Biologica, Oeiras 2780 157, Portugal; ${ }^{5}$ Centro de Geociências, Universidade \\ Federal do Pará, Belém CP 66075 110, Brazil; ${ }^{6}$ Coordenaçao de Botânica, Museu Paraense Emilio Goeldi, Belém CP \\ 66077 830, Brazil; ${ }^{7}$ Department of Plant Physiology, Umeå Plant Science Centre, Umeå University, Umeå SE 90187, \\ Sweden; and ${ }^{8}$ School of Geosciences, University of Edinburgh, Edinburgh EH8 9XP, UK
}

\begin{abstract}
Summary
1. The Amazon region may experience increasing moisture limitation over this century. Leaf dark respiration $(R)$ is a key component of the Amazon rain forest carbon $(\mathrm{C})$ cycle, but relatively little is known about its sensitivity to drought.

2. Here, we present measurements of $R$ standardized to $25^{\circ} \mathrm{C}$ and leaf morphology from different canopy heights over 5 years at a rain forest subject to a large-scale through-fall reduction (TFR) experiment, and nearby, unmodified Control forest, at the Caxiuanã reserve in the eastern Amazon.

3. In all five post-treatment measurement campaigns, mean $R$ at $25^{\circ} \mathrm{C}$ was elevated in the TFR forest compared to the Control forest experiencing normal rainfall. After 5 years of the TFR treatment, $R$ per unit leaf area and mass had increased by $65 \%$ and $42 \%$, respectively, relative to pre-treatment means. In contrast, leaf area index $(L)$ in the TFR forest was consistently lower than the Control, falling by $23 \%$ compared to the pre-treatment mean, largely because of a decline in specific leaf area $(S)$.

4. The consistent and significant effects of the TFR treatment on $R, L$ and $S$ suggest that severe drought events in the Amazon, of the kind that may occur more frequently in future, could cause a substantial increase in canopy carbon dioxide emissions from this ecosystem to the atmosphere.
\end{abstract}

Key-words: tropical forest, climate change, moisture deficit, leaf dark respiration, night-time foliar carbon emissions, specific leaf area, leaf area index, through-fall exclusion experiment

\section{Introduction}

Leaf dark respiration $(R)$ of carbon dioxide $\left(\mathrm{CO}_{2}\right)$ is a key component of the Amazon rain forest ecosystem carbon $(\mathrm{C})$ cycle but remains poorly understood and rarely measured, compared to other ecosystem fluxes such as photosynthesis and soil $\mathrm{CO}_{2}$ efflux (Malhi, Baldocchi \& Jarvis 1999; Chambers et al. 2004b; Meir et al. 2008). This lack of knowledge impedes attempts to predict the impacts of current and

*Correspondence author. E-mail: daniel.metcalfe@ouce.ox.ac.uk future environmental change upon $\mathrm{C}$ cycling in the Amazon rain forest.

In the case of the Amazon, of particular interest is the effect of water availability upon $R$ because the region may experience increasingly frequent and severe drought events associated with global climate change, fire and deforestation over the next 100 years (Werth \& Avissar 2002; Christensen et al. 2007; Cox et al. 2008; Harris, Huntingford \& Cox 2008; Malhi et al. 2008). Previous periods of drought during El Niño events have appeared to cause a shift in regional scale $\mathrm{C}$ exchange across the entire Amazon forest from a net $\mathrm{C}$ sink to a source of up to $1.5 \times 10^{9} \mathrm{t} \mathrm{C}$ year $^{-1}$ 
(Roedenbeck et al. 2003; Zeng, Mariotti \& Wetzel 2005). Models that simulate the interactions between forest and atmosphere have been able to approximate this inter-annual pattern of regional $\mathrm{C}$ fluxes by simulating a simultaneous decline in $\mathrm{C}$ uptake via photosynthesis and a rise in ecosystem respiration during drier and warmer years (Tian et al. 1998; Peylin et al. 2005; Zeng, Mariotti \& Wetzel 2005). Several studies have attempted to experimentally corroborate these model predictions. While there is reasonable supporting evidence for a drought-induced reduction in photosynthesis (Chaves \& Oliveira 2004; Flexas et al. 2004; Fisher et al. 2007), most available data on ecosystem respiration suggest that it decreases under dry conditions (Saleska et al. 2003; Vourlitis et al. 2005; Hutyra et al. 2007; Meir et al. 2008). Much of this drought-induced inhibition may be attributable to a decline in the largest single component of ecosystem respiration-soil $\mathrm{CO}_{2}$ efflux (Davidson et al. 2000; Schwendenmann et al. 2003; Sotta et al. 2004, 2007; Metcalfe et al. 2007).

However, ecosystem respiration is a composite flux derived from not only soil $\mathrm{CO}_{2}$ efflux but also $R$ and other sources, which may each respond to environmental change in different ways. Foliar $\mathrm{C}$ emissions per unit ground area are the integrated product of $R$, leaf area index $(L)$ and the vertical distribution of $R$ and $L$ through the forest canopy. $L$, in turn, is the product of foliar biomass per unit ground area $(M)$ and specific leaf area $(S)$. All of these parameters are potentially sensitive to changes in water availability (Nepstad et al. 2002; Hanson \& Wullschleger 2003; Miranda et al. 2005; Wright et al. 2006; Fisher et al. 2007; Myneni et al. 2007; Brando et al. 2008). There currently exists relatively little information about the individual responses of $R, S, L$ and $M$ to drought in the Amazon and even fewer data on the net effect of droughtinduced changes in these parameters upon stand-scale foliar $\mathrm{C}$ emissions. Thus, it remains unclear to what extent measured responses of Amazon forest soil $\mathrm{CO}_{2}$ efflux may be offset or accentuated by simultaneous shifts in foliar $\mathrm{C}$ emissions.

The overall objective of this study, therefore, was to assess the sensitivity to drought of $R, S, L$ and $M$ at an eastern Amazon rain forest site. The impact of sustained drought was estimated by comparing measurements made in a 1-ha plot where c. $50 \%$ of incident rainfall had been excluded (through-fall reduction or TFR plot) to an adjacent, similar but unmodified, Control plot. While the TFR treatment was not replicated (Hurlbert 1984, 2004) because of logistical and financial constraints, it did provide insights into ecosystem processes that would otherwise have been impossible to capture in smaller scale, more easily replicated experiments (Reviews: Carpenter 1996; Sullivan 1997; Osmond et al. 2004; Stokstad 2005; Field studies: Nepstad et al. 2002; Davidson, Ishida \& Nepstad 2004; Fisher et al. 2007; Metcalfe et al. 2007; Sotta et al. 2007; Brando et al. 2008). Specifically, we used a 'before-after-control-impact' (Underwood 1997; Rasmussen et al. 2001; Gotelli \& Ellison 2004) approach to test for significant shifts in $R$ and $S$ both (i) Over time- before and after the imposition of the TFR treatment and between dry and wet seasons, and (ii) Between the TFR treatment and Control for each individual measurement campaign. Finally, we use existing $L$ data to upscale leaf-level $R$ measurements to derive plot estimates of foliar night-time $\mathrm{C}$ effluxes.

\section{Materials and methods}

\section{STUDY SITE}

The experimental site is located in the Caxiuanã National Forest, Pará State, north-eastern Brazil $\left(1^{\circ} 43^{\prime} 3 \cdot 5^{\prime \prime} \mathrm{S}, 51^{\circ} 27^{\prime} 36^{\prime \prime} \mathrm{W}\right)$. The forest is a lowland terra firme rain forest situated on a level plain $10-15 \mathrm{~m}$ above river water level, with a high annual rainfall $(\sim 2500 \mathrm{~mm})$ and a pronounced seasonality in leaf fall which peaks during the strong dry season (see Table 1 for additional plot details). Plant species diversity is high at around 100 species per hectare, of which over half are Sapotaceae, Fabaceae, Violaceae and Chrysobalanacae, and less than 1\% are lianas. Mean annual air temperature is $c .25^{\circ} \mathrm{C}$ and the diurnal variation is typically less than $3{ }^{\circ} \mathrm{C}$. The most widespread soil type is a highly weathered yellow Oxisol (US Department of Agriculture soil taxonomy). In January 2002, a 1-ha area of forest was modified with the installation of plastic panels at $2 \mathrm{~m}$ height to exclude $c .50 \%$ of incident rainfall (TFR plot). This reduction in rainfall is similar to a key early long-term climate prediction for the region (Cox et al. 2000). The perimeter of the TFR plot was trenched to a mean depth of $1 \mathrm{~m}$ and lined with plastic sheeting to minimize lateral flow of water into the site. Intercepted water was channelled away to a run-off area $50 \mathrm{~m}$ away from the plot. An adjacent 1-ha Control plot with similar topography, soil type and vegetation structure (Fisher et al. 2007) was used to assess natural patterns of $L, S$ and $R$, in the absence of any TFR treatment. Supplementary measurements during the first 3 years of the TFR treatment demonstrated that soil water potential, tree stem sapflow, stomatal conductance and photosynthesis were all substantially reduced in the TFR plot compared to the Control, particularly during the dry season (Fisher et al. 2007). At the beginning of the experiment in January 2001,30 m tall canopy access towers were installed near the centre of both plots. All measurements were

Table 1. Key vegetation and soil features for each plot surveyed

\begin{tabular}{lrr}
\hline Plot characteristics & Control & TFR \\
\hline Vegetation & & \\
Tree number ha ${ }^{-1}$ & 434 & 421 \\
Stem basal area $\left(\mathrm{m}^{2} \mathrm{ha}^{-1}\right)$ & $23 \cdot 9$ & $24 \cdot 0$ \\
Tree species ha & 118 & 113 \\
Soil $0-10 \mathrm{~cm}$ & & \\
Clay content $(\%)$ & 18 & 13 \\
Silt content $(\%)$ & 5 & 4 \\
Sand content $(\%)$ & 77 & 83 \\
pH & 4 & 4 \\
Carbon content $\left(\mathrm{g} \mathrm{kg}^{-1}\right)$ & 9 & 12 \\
Nitrogen content $\left(\mathrm{g} \mathrm{kg}^{-1}\right)$ & $0 \cdot 4$ & $0 \cdot 3$ \\
Phosphorus content $\left(\mathrm{mg} \mathrm{dm}^{-3}\right)$ & 3 & 3 \\
Carbon : nitrogen ratio & 23 & 35 \\
Soil cation exchange $\left(\mathrm{cmol} \mathrm{dm}^{-3}\right)$ & $0 \cdot 8$ & $0 \cdot 7$ \\
\hline
\end{tabular}

TFR, through-fall reduction. Tree number and basal area represents all individuals over $10 \mathrm{~cm}$ diameter at breast height, measured in January 2005. Soil values are collated from data in Sotta et al. (2007). 
taken at least $20 \mathrm{~m}$ inside the perimeter of each plot to minimize edge effects.

\section{MEASUREMENT OF LEAF DARK RESPIRATION AND SPECIFIC LEAF AREA}

$R$ and $S$ from trees on both plots were recorded on six occasions between November 2001 and January 2007: once before and five times after imposition of the TFR treatment. $L$ data are also available from the same periods on both plots (Fisher et al. 2007). All measurement campaigns sampled fully expanded, non-senescent, un-diseased leaves, and recorded additional information about the height and tree species of the sampled leaves. Thus, $R$ measurements from these leaves should primarily reflect 'maintenance' respiration rather than 'growth' respiration associated with metabolic costs of constructing new plant tissue (McCree 1970). All leaves were sampled during the daytime (08.30-15.00 h) and kept in the dark until $\mathrm{CO}_{2}$ gas exchange had stabilized (usually after $5-10 \mathrm{~min}$ ) before $R$ at ambient air $\mathrm{CO}_{2}$ concentration (360-380 p.p.m.) and humidity $(60-80 \%)$ was recorded, thus minimizing biases potentially introduced by lightenhanced dark respiration and the photorespiratory post-illumination burst (Atkin, Evans \& Siebke 1998).

The first five measurement campaigns (conducted between November 2001 and 2003) used the following methodology: 17-26 leaves from nine trees, and 18-26 leaves from eight trees were sampled around the canopy access towers on the Control and TFR plots respectively (Table 2). Measurements were taken from the same trees and from leaves at the same canopy heights in each measurement campaign. $R$ was measured in situ from un-excised leaves with an infra-red gas analyser (IRGA) connected to a leaf measurement cuvette (LI-COR 6400 portable photosynthesis system with 6400-02B leaf cuvette; Lincoln, NE, USA). Leaf discs of a known area were cut from leaves on the same branch as leaves used for $R$ measurement, dried at $70{ }^{\circ} \mathrm{C}$ until constant mass and weighed. $S$ was calculated for each leaf disc sampled by dividing dry mass by one-sided area.

The final measurement campaign (in January 2007) sampled a total of 33 and 28 individual leaves from the Control and TFR plots, respectively, from 15 separate trees per plot. Of these trees sampled, 10 were randomly selected as the closest tree to every $10 \mathrm{~m}$ intersection point along two $40 \mathrm{~m}$ long transects in the centre of the plot. A branch from the outer canopy of each selected tree was excised at between one and three different canopy heights. No attempt was made to cut and re-cut branches under water because this would not have guaranteed that gas exchange remained unaltered (Santiago \&

Table 2. Tree species sampled on the plots

\begin{tabular}{ll}
\hline Control & TFR \\
\hline Duguetia echinophora & Duguetia echinophora \\
Hasseltia floribunda & Hirtela bicornis \\
Licania heteromorpha & Lecythis confertiflora \\
Manilkara bidentata & Licaria armeniaca \\
Mezilaurus lindawiana & Licania canescens \\
Pouteria lateriflora & Manilkara paraensis \\
Protium heptaphyllum & Mouriri duckeana \\
Quiina florida & Swartzia racemosa \\
\hline
\end{tabular}

TFR, through-fall reduction. An individual representative of each species (two individuals of Quiina florida on the Control plot) was repeatedly sampled between November 2001 and 2003. In the final measurement campaign (January 2007) trees sampled were not identified to species level.
Mulkey 2003). Instead, we designed an experiment to quantify and, if necessary, correct for any impacts of branch excision (see text in Methods section). To facilitate sampling of leaves higher up in the emergent canopy and to replicate measurements on individual trees made earlier, an additional five trees per plot were similarly sampled around the canopy access towers on each plot. $R$ was measured for most leaves within $3 \mathrm{~h}$ of branch excision, using an IRGA connected to a leaf measurement cuvette (CIRAS-1 IRGA with PLC6 leaf cuvette; PP Systems, Hitchen, UK). The interval of time between branch excision and $R$ measurement was noted for each leaf sampled. There was no significant difference in the mean time between excision and $R$ measurement on the plots.

After measurement, the same leaves were photographed to calculate leaf area with digital image analysis, and then dried at $70{ }^{\circ} \mathrm{C}$ until constant mass and weighed. $S$ was calculated for each entire leaf sampled (including petioles) by dividing dry mass by one-sided area.

Measurements made with the LI-COR 6400 IRGA maintained a flow rate of $500 \mu \mathrm{mol} \mathrm{s}^{-1}$, with a mean \pm standard error (SE) difference between $C_{\mathrm{r}}$ and $C_{\mathrm{s}}$ of $0.52 \pm 0.07$ p.p.m. The CIRAS-1 IRGA was set to a lower flow rate of $200 \mu \mathrm{mol} \mathrm{s}{ }^{-1}$, and consequently the observed mean $\pm \mathrm{SE} \mathrm{CO}_{2}$ difference was $0.91 \pm 0.06$ p.p.m. The inward diffusion of respired $\mathrm{CO}_{2}$ from leaf material clamped under the cuvette gasket (Pons \& Welschen 2002) and the diluting effect of water vapour produced by the leaf was corrected for.

Leaf temperatures recorded automatically by the IRGA systems during $R$ measurement varied between 22 and $31{ }^{\circ} \mathrm{C}$. Species-specific $R$ temperature response functions were not available for all of the trees sampled, so measurements were standardized to a reference temperature of $25^{\circ} \mathrm{C}\left(R_{25}\right)$ with the following formula that describes the average $R$ temperature response across 116 terrestrial plant species (Atkin \& Tjoelker 2003; Atkin, Bruhn \& Tjoelker 2005):

$R_{25}=R_{\alpha}\left\{3 \cdot 09-0 \cdot 0435\left[25+T_{\alpha}\right] / 2\right\}^{\left[\left(25-T_{\alpha}\right) / 10\right]}$

where $R_{\mathrm{a}}$ is $R$ recorded at ambient temperature $\left(T_{\mathrm{a}}\right)$.

To investigate the potential confounding influences of branch excision on the $R$ values recorded in January 2007, the following experiment was devised. An un-excised leaf was placed within the IRGA cuvette and $R$ was measured every minute for $1 \mathrm{~h}$. After this period, the branch attached to the leaf within the cuvette was excised, but $R$ measurement was continued at the same temporal frequency for $5 \mathrm{~h}$, to observe whether there was any change in $R$ with time since branch excision. Over this period, the sensor was regularly automatically calibrated with air passed through a molecular sieve to remove all $\mathrm{CO}_{2}$. Before and during measurements the molecular sieve was frequently checked to ensure that it was not exhausted. This procedure was repeated three times, on consecutive days from three individual leaves each on separate trees of different species. All leaves sampled showed no change in $R$ over the hour prior to excision, but after excision $R$ rose gradually over time, approximately doubling after $5 \mathrm{~h}$ compared to the pre-excision mean value (data not shown). A third-order polynomial model was fitted to the mean trend of $R$ over time since branch excision $\left(R^{2}=0 \cdot 77\right)$. This model was not chosen as a realistic mechanistic simulation of plant gas exchange, but purely for limited predictive purposes over the duration of the measurements because it provided the best fit to the data. This equation, together with data collected on the interval of time between branch excision and $R$ measurements for each leaf, was used to correct for the confounding effect of excision and storage on January 2007 measurements by calculating $R$ at time since excision $=0$ for each leaf sampled. No immediate effect of excision itself on $R$ was apparent. 


\section{MEASUREMENT OF LEAF AREA INDEX AND FOLIAGE MASS}

Mean plot $L$ estimated during the first five measurement campaigns (conducted between November 2001 and 2003) is presented in Fisher et al. (2007). These data were derived from canopy images captured at 100 points per plot with LAI-2000 plant canopy analysers (LICOR Inc.). For this study, additional $L$ data were collected in January 2007 based upon canopy images per plot collected at 25 locations along a with a digital camera and fish-eye lens (Nikon Coolpix 900; Nikon Corporation, Melville,USA) and subsequently analysed with digital image analysis software (Hemiview 2.1 SR1; Delta-T Devices Ltd, Cambridge, UK). All images of the canopy were recorded in the early morning or late afternoon, during periods of fully diffuse incoming radiation along a regular grid within both plots (following the methodology of Aragão et al. (2005). The distribution of $L$ with height above the ground on both plots was estimated once - in November 2001 - by recording $L$ with the LAI-2000 plant canopy analysers (LI-COR Inc.) every $2 \mathrm{~m}$ up each of the plot canopy access towers. Plot-level $M$ was estimated for each measurement campaign by multiplying mean plot leaf mass per unit leaf area $(1 / S)$ by $L$.

\section{ESTIMATING STAND-SCALENIGHT-TIME FOLIAR CARBON EFFLUX}

To illustrate how $R, S$ and $L$ interact, and to facilitate direct comparison of our leaf-level $R$ measurements with other ecosystem $C$ fluxes, we derived approximate estimates of stand-scale foliar C efflux. To do so, we calculated mean $\pm 95 \%$ confidence intervals of $L$ and $R$ per unit area separately for three canopy height layers $(\leq 10,11-20$, $\geq 21 \mathrm{~m}$ ). Night-time foliar $\mathrm{C}$ emissions per unit ground area were estimated for each canopy layer as the product of $R$ per unit leaf area multiplied by $L$. Given the low temporal frequency of our direct measurements and the focus on between-plot (rather than seasonal or annual) differences we opted for the relatively simple, more transparent, up-scaling approach of assuming constant night-time air temperature of $25^{\circ} \mathrm{C}$ and $12 \mathrm{~h}$ of dark conditions each day throughout the year. For the purposes of this analysis, we also assumed that darkequilibrated $R$ recorded during the day in this study was representative of night-time leaf respiration (Chambers et al. 2009; but see Hubbard, Ryan \& Lukens 1995). Means from each canopy layer were summed to derive total plot estimates. Where necessary, $95 \%$ confidence intervals were propagated by quadrature of absolute errors for addition and subtraction, and quadrature of relative errors for multiplication and division (Mood, Graybill \& Boes 1974; Cavaleri, Oberhauer \& Ryan 2008). This assumes that errors are independent and normally distributed.

\section{DATA ANALYSIS}

To assess the impact of the TFR treatment on $S$ and $R$ the following two statistical analyses were performed. (i) Within-plot change over time since the imposition of the TFR treatment was quantified with a repeated-measures analysis of variance (RM-ANOVA). Data from the final measurement campaign were not included in the RM-ANOVA because a different set of trees were sampled with a different methodology, whereas the previous five campaigns repeatedly sampled leaves from the same trees and same canopy heights. To examine specifically which time periods differed from each other in terms of $S$ and $R$, pairwise comparisons between measurement campaigns were conducted within the RM-ANOVA analysis. (ii) Between-plot differences in $R$ and $S$ over all measurement campaigns were quantified with a Generalized Linear Model (GLM) with plot as a fixed-effects factor, and leaf height, tree family and sampling time specified as random-effects factors to control for the potentially confounding effect of sampling differences between plots. Using this method, plot differences were examined both for all data at each measurement campaign, and for all data in different canopy height categories $(\leq 10,11-$ $20, \geq 21 \mathrm{~m}$ ). In addition, the links between leaf height, $R$ and $S$ were assessed with a Spearman's Rank Correlation. Statistical analyses were carried out with SPSS $14 \cdot 0$ for Windows (SPSS Inc., Chicago, IL, USA). Key outputs of the analyses were an $F$-statistic (for the RM-ANOVA and GLM), a correlation coefficient ( $r$, for the Spearman's Rank Correlation analysis) and a significance $P$-value for all tests. Data were transformed with a natural logarithm, where necessary, to conform to the assumptions of parametric analysis.

\section{Results}

\section{PLOT TRENDS IN STAND-SCALE NIGHT-TIME FOLIAR CARBONEFFLUX}

$R$ per unit area together with $L$ data, apportioned into canopy height categories $(\leq 10,11-20, \geq 21 \mathrm{~m})$, were used to estimate total $\pm 95 \%$ confidence intervals foliar night-time C emissions prior to the TFR treatment of $3 \cdot 4 \pm 0 \cdot 1$ and $3 \cdot 4 \pm 0 \cdot 3 \mathrm{t} \mathrm{ha}^{-1}$ year $^{-1}$ on the Control and TFR plots respectively (Table 3 ). According to these estimates, elevated $R$ on the TFR plot relative to the Control was not fully offset by the drought-associated decline in $L$, such that night-time foliar $\mathrm{C}$ emissions on the TFR plot were $0.7 \pm 0.4$ and $1.8 \pm 0.9 \mathrm{t} \mathrm{C} \mathrm{ha}^{-1}$ year $^{-1}$ greater than the Control plot based upon measurements in November 2003 and January 2007 respectively (Table 3).

\section{PLOT TRENDS IN LEAF DARK RESPIRATION}

Plot mean $R$ values were comparable to existing data from other studies in the Amazon forest (Table 4). In the Control plot, there was no significant overall change in $R$ per unit area (RM-ANOVA, d.f. $=4, F=0.77, P=0.56$ ) and mass (RM-ANOVA, d.f. $=4, \quad F=1 \cdot 78, \quad P=0.17$ ) between November 2001 and 2003 (Table 5, Fig. 1c,d). In contrast,

Table 3. Plot estimates of night-time stand-scale foliar C efflux ( $\mathrm{C} \mathrm{ha}^{-1}$ year $\left.^{-1}\right)$

\begin{tabular}{|c|c|c|c|c|c|c|}
\hline & November 2001 & May 2002 & November 2002 & May 2003 & November 2003 & January 2007 \\
\hline Control & $3 \cdot 4 \pm 0 \cdot 1$ & $4 \cdot 0 \pm 0 \cdot 4$ & $4 \cdot 2 \pm 1 \cdot 9$ & $3.5 \pm 0.6$ & $4 \cdot 6 \pm 0 \cdot 2$ & $4 \cdot 1 \pm 0 \cdot 4$ \\
\hline TFR & $3 \cdot 4 \pm 0 \cdot 3$ & $4 \cdot 2 \pm 0 \cdot 4$ & $3 \cdot 1 \pm 0 \cdot 2$ & $4 \cdot 8 \pm 1 \cdot 1$ & $5 \cdot 3 \pm 0 \cdot 3$ & $5 \cdot 9 \pm 0 \cdot 8$ \\
\hline Difference TFR - Control & $0 \cdot 0 \pm 0 \cdot 4$ & $0 \cdot 2 \pm 0 \cdot 6$ & $-1 \cdot 1 \pm 1 \cdot 9$ & $1 \cdot 4 \pm 1 \cdot 2$ & $0 \cdot 7 \pm 0 \cdot 4$ & $1 \cdot 8 \pm 0 \cdot 9$ \\
\hline
\end{tabular}

TFR, through-fall reduction. Values are estimated from instantaneous measurements at each date extrapolated over a year assuming constant air temperature of $25^{\circ} \mathrm{C}$ and $12 \mathrm{~h}$ of dark conditions every night. 
Table 4. A summary of available data on respiration per unit area at $25{ }^{\circ} \mathrm{C}$ from leaves at primary lowland terra firme rain forest sites in the Amazon

\begin{tabular}{|c|c|c|c|}
\hline Source & Coordinates & $\begin{array}{l}\text { Respiration } \\
\left(\mu \mathrm{mol} \mathrm{m} \mathrm{m}^{-2} \mathrm{~s}^{-1}\right)\end{array}$ & Notes \\
\hline Reich et al. (1998) & $1^{\circ} 56^{\prime} \mathrm{N}, 67^{\circ} 03^{\prime} \mathrm{W}$ & $0.91 \pm 0.23^{*}$ & \\
\hline Meir, Grace \& Miranda (2001) & $10^{\circ} 05^{\prime} \mathrm{S}, 61^{\circ} 55^{\prime} \mathrm{W}$ & $0 \cdot 36 \pm 0.20 \dagger$ & \\
\hline \multirow[t]{2}{*}{ Domingues et al. (2005) } & $3^{\circ} 33^{\prime} \mathrm{S}, 55^{\circ} 83^{\prime} \mathrm{W}$ & $0 \cdot 43 \pm 0.36 t$ & Wet season \\
\hline & & $0.57 \pm 0.39 \ddagger$ & Dry season \\
\hline \multirow[t]{2}{*}{ Miranda et al. (2005) } & $11^{\circ} 25^{\prime} \mathrm{S}, 55^{\circ} 20^{\prime} \mathrm{W}$ & $0 \cdot 33 \pm 0 \cdot 17 t$ & Wet season \\
\hline & & $0.66 \pm 0 \cdot 37 \ddagger$ & Dry season \\
\hline Cavaleri, Oberhauer \& Ryan (2008) & $10^{\circ} 20^{\prime} \mathrm{N}, 83^{\circ} 50^{\prime} \mathrm{W}$ & $0.59 \pm 0.44 \dagger$ & \\
\hline \multirow[t]{4}{*}{ This study } & $1^{\circ} 43^{\prime} 3 \cdot 5^{\prime \prime} \mathrm{S}, 51^{\circ} 27^{\prime} 36^{\prime \prime} \mathrm{W}$ & $0 \cdot 32 \pm 0 \cdot 13 \ddagger$ & Control plot, November 2001 \\
\hline & & $0 \cdot 33 \pm 0 \cdot 17 \ddagger$ & TFR plot, November 2001 \\
\hline & & $0 \cdot 41 \pm 0 \cdot 20 \ddagger$ & Control plot, January 2007 \\
\hline & & $0.55 \pm 0 \cdot 27 t$ & TFR plot, January 2007 \\
\hline
\end{tabular}

TFR, through-fall reduction. Respiration values represent mean \pm standard deviation. Respiration data collected in this study in November 2001 and January 2007 used different methods and sampling strategies.

* Measured at $25^{\circ} \mathrm{C}$.

$\dagger$ Corrected to $25^{\circ} \mathrm{C}$ using site-specific temperature response curves.

$\$$ Corrected to $25^{\circ} \mathrm{C}$ using a generic temperature response curve (Atkin \& Tjoelker 2003; Atkin, Bruhn and Tjoelker 2005).
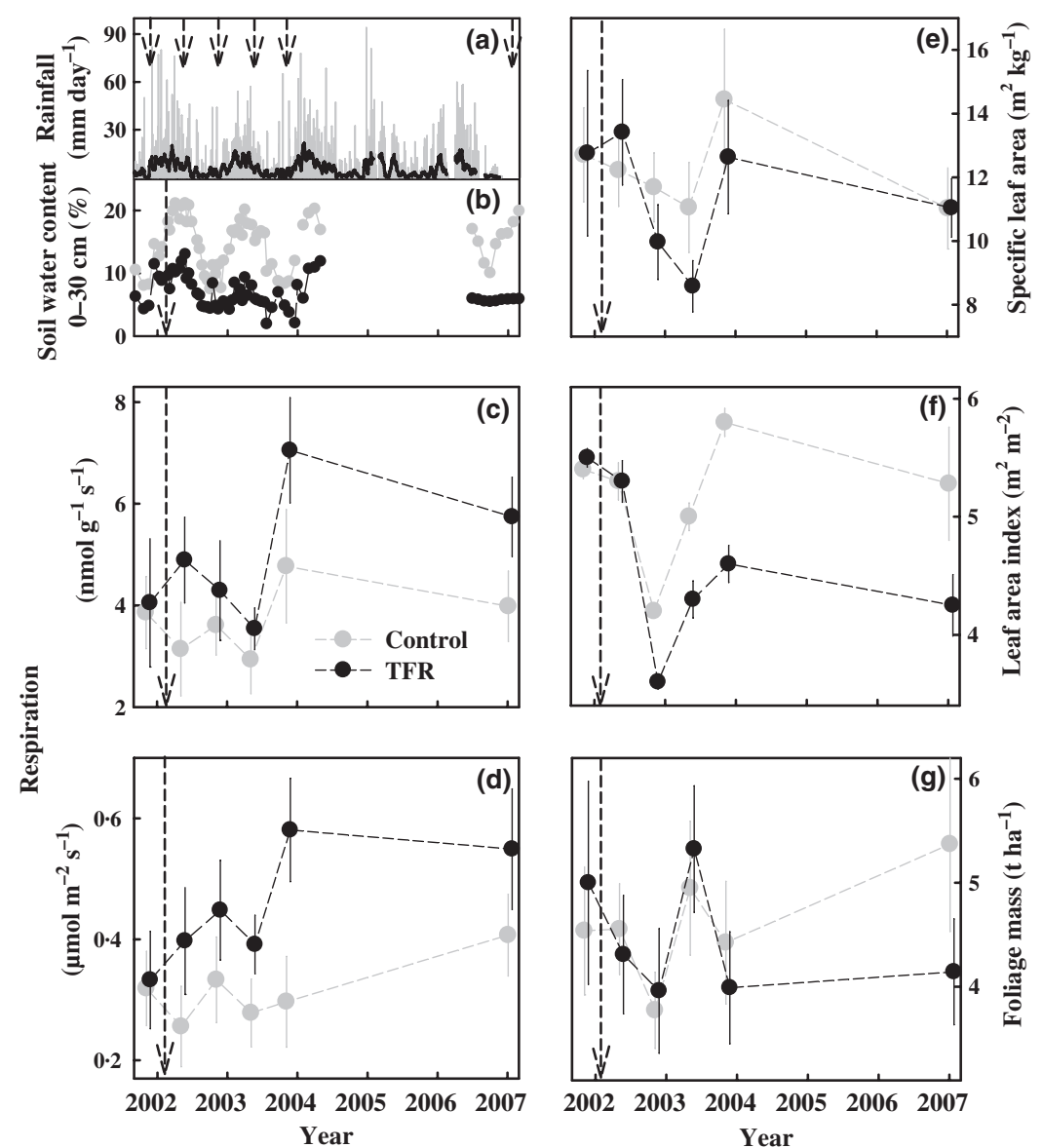

Fig. 1. Seasonal trends in site rainfall (a), plot surface soil water content (b), respiration per unit mass (c) and area (d), specific leaf area (e), leaf area index (f) and foliage mass (g) over the study period. Values denote plot means $\pm 95 \%$ confidence intervals. TFR, through-fall reduction. Rainfall is presented both on a daily basis (grey) and as a 15-day running average (black). The vertical dashed arrows in (a) mark leaf sampling times, and in (b)-(g) mark the date of TFR treatment establishment. $L$ data for the measurement campaigns between November 2001 and 2003 are reproduced from Fisher et al. (2007).

over the same period on the TFR plot, $R$ per unit area (RMANOVA, d.f. $=4, F=5 \cdot 24, P=0 \cdot 004)$ and mass (RMANOVA, d.f. $=4, F=5 \cdot 14, P=0 \cdot 004)$ increased significantly (Table 5, Fig. 1c,d). Specifically, while $R$ per unit area on the TFR plot began to rise immediately after imposition of the treatment (Table 5, Fig. 1d), it only became significantly higher compared to pre-treatment values during the peaks of the dry season in November 2002 (RM-ANOVA pairwise comparison, $P=0.011$ ) and 2003 (RM-ANOVA pairwise comparison, $P=0.003)$. $R$ per unit mass showed a slightly different temporal trend following the TFR treatment (Table 5, Fig. 1c) becoming significantly higher compared to 
Table 5. Significance $P$-values for differences in respiration and specific area from branches re-sampled over five successive measurement campaigns in both plots

\begin{tabular}{|c|c|c|c|c|}
\hline $\begin{array}{l}\text { November } \\
2001\end{array}$ & $\begin{array}{l}\text { May } \\
2002\end{array}$ & $\begin{array}{l}\text { November } \\
2002\end{array}$ & $\begin{array}{l}\text { May } \\
2003\end{array}$ & $\begin{array}{l}\text { November } \\
2003\end{array}$ \\
\hline \multicolumn{5}{|c|}{ Respiration per unit area } \\
\hline \multicolumn{5}{|c|}{ Control plot } \\
\hline \multicolumn{5}{|l|}{ November 2001} \\
\hline May 2002 & $\mathbf{0} \cdot 21$ & & & \\
\hline November 2002 & 0.94 & $0 \cdot 08$ & & \\
\hline May 2003 & $0 \cdot 28$ & $0 \cdot 88$ & $0 \cdot 40$ & \\
\hline November 2003 & $0 \cdot 89$ & $0 \cdot 44$ & $0 \cdot 89$ & $0 \cdot 22$ \\
\hline \multicolumn{5}{|l|}{ TFR plot } \\
\hline \multicolumn{5}{|c|}{ November 2001} \\
\hline May 2002 & $0 \cdot 31$ & & & \\
\hline November 2002 & 0.011* & $0 \cdot 19$ & & \\
\hline May 2003 & $0 \cdot 21$ & $0 \cdot 75$ & $0 \cdot 28$ & \\
\hline November 2003 & $0.003^{* *}$ & $0 \cdot 01^{* *}$ & $0 \cdot 27$ & $0 \cdot 06$ \\
\hline \multicolumn{5}{|c|}{ Respiration per unit mass } \\
\hline \multicolumn{5}{|c|}{ Control plot } \\
\hline \multicolumn{5}{|l|}{ November 2001} \\
\hline May 2002 & $0 \cdot 16$ & & & \\
\hline November 2002 & $0 \cdot 45$ & $0 \cdot 13$ & & \\
\hline May 2003 & $0 \cdot 31$ & 0.98 & $0 \cdot 64$ & \\
\hline November 2003 & $0 \cdot 28$ & $0 \cdot 13$ & $0 \cdot 30$ & $0 \cdot 042^{*}$ \\
\hline \multicolumn{5}{|l|}{ TFR plot } \\
\hline \multicolumn{5}{|l|}{ November 2001} \\
\hline May 2002 & $0 \cdot 25$ & & & \\
\hline November 2002 & $0 \cdot 48$ & $0 \cdot 89$ & & \\
\hline May 2003 & 0.52 & $0 \cdot 038^{*}$ & $0 \cdot 17$ & \\
\hline November 2003 & $0.027^{*}$ & $0.045^{*}$ & $0 \cdot 08$ & $0 \cdot 004^{* *}$ \\
\hline \multicolumn{5}{|l|}{ Specific leaf area } \\
\hline \multicolumn{5}{|l|}{ Control plot } \\
\hline \multicolumn{5}{|l|}{ November 2001} \\
\hline May 2002 & 0.60 & & & \\
\hline November 2002 & $0.049 *$ & $0 \cdot 25$ & & \\
\hline May 2003 & $0 \cdot 42$ & 0.74 & $0 \cdot 63$ & \\
\hline November 2003 & $0 \cdot 23$ & $0 \cdot 12$ & $0.047^{*}$ & $0.014^{*}$ \\
\hline \multicolumn{5}{|l|}{ TFR plot } \\
\hline \multicolumn{5}{|l|}{ November 2001} \\
\hline May 2002 & 0.51 & & & \\
\hline November 2002 & $0 \cdot 24$ & $0 \cdot 016^{*}$ & & \\
\hline May 2003 & 0.07 & $0 \cdot 002 * *$ & $0 \cdot 039^{*}$ & \\
\hline November 2003 & 0.93 & $0 \cdot 31$ & $0 \cdot 08$ & \\
\hline
\end{tabular}

TFR, through-fall reduction. Values are derived from an RMANOVA pairwise comparison. Significant $(P<0.05)$ and very significant $(P<0.01)$ differences are marked with single and double asterisks respectively. Values in bold highlight differences compared to data collected prior to imposition of the TFR treatment (November 2001).

the pre-treatment mean only by November 2003 (RM-ANOVA pairwise comparison, $P=0 \cdot 027$ ).

Directly comparing plot $R$ estimates from each measurement campaign and controlling for plot sampling differences in tree family, leaf height and sampling time showed that there was no significant plot difference in $R$ per unit area (GLM, d.f. $=1, F=0.30, P=0.68)$ and mass (GLM, d.f. $=1, F=4 \cdot 34, P=0.28)$ prior to imposition of the TFR treatment (Fig. 1c,d). However, after the TFR treatment, measured $R$ on the TFR plot increased (Table 5, Fig. 1c,d) until it became significantly higher than the Control in January 2007 (GLM, d.f. = 1, Per unit mass:
$F=6 \cdot 12, P=0.035$; Per unit area: $F=16.91, P=0.002)$. This plot difference in $R$ was mainly attributable to a significantly lower rate of $R$ per unit mass (GLM, d.f. $=1$, $F=28.38, \quad P<0.001)$ and area (GLM, d.f. $=1$, $F=45.77, P<0.001)$ in lower canopy leaves ( $\leq 10 \mathrm{~m}$ above the ground surface) on the TFR plot compared to the Control (Fig. 2a,b). No significant plot difference was found in upper canopy leaves ( $\geq 21 \mathrm{~m}$ above the ground surface).

There was a highly significant positive correlation between leaf height above the ground and $R$ per unit area in the Control plot (Fig. 2b, Spearman's Rank Correlation, $n=147$, $r=0.48, P<0.001$ ), while on the TFR plot the trend was weaker but still present (Fig. 2b, Spearman's Rank Correlation, $n=141, r=0 \cdot 16, P=0 \cdot 054)$. However, when quantified on a per unit mass basis, $R$ in the Control plot ceased to show any significant pattern of change with leaf height above the ground (Fig. 2a).

\section{PLOT TRENDS IN SPECIFIC LEAF AREA}

Overall, $S$ showed significant change over time in both the Control (Table 5, Fig. 1e, RM-ANOVA, d.f. $=4$, $F=3 \cdot 16, P=0 \cdot 036$ ) and TFR plots (Table 5, Fig. 1e, RMANOVA, d.f. $=4, F=4.34, P=0.009)$. However, this change reflected bidirectional seasonal and annual variation (Fig. 1e) rather than progressive unidirectional change over time: in the Control plot only mean $S$ measured in November 2002 was significantly different from the pre-treatment mean (Table 5, RM-ANOVA pairwise comparison, $P=0.049$ ) while none of the $S$ measurements in the TFR plot diverged significantly from initial values recorded in November 2001 (Table 5). Once variation derived from sampling differences was excluded, no significant difference in $S$ between plots during any individual measurement campaign was found. Neither was there any significant plot difference in mean $S$ in the different canopy height categories (Fig. 2), although on both plots, leaves in the upper canopy tended to have lower $S$ compared to understorey leaves (Fig. 3c, Control plot: Spearman's Rank Correlation, $n=135, r=-0.56, P<0 \cdot 001$; TFR plot: Spearman's Rank Correlation, $n=129$, $r=-0.54, P<0.001)$.

\section{PLOT TRENDS IN LEAF AREA INDEX}

Before imposition of the TFR treatment both plots had similar $L\left(\sim 5.5 \mathrm{~m}^{2} \mathrm{~m}^{-2}\right)$, but after the treatment $L$ on the TFR plot declined, reaching a value of $c .4 .5 \mathrm{~m}^{2} \mathrm{~m}^{-2}\left(\sim 1 \mathrm{~m}^{2} \mathrm{~m}^{-2}\right.$ or $20 \%$ lower than the Control) after almost 2 years of the TFR treatment (Fig. 1f). On both plots, there was an abrupt and substantial decline in $L$ measured during November 2002 which was gradually recovered over subsequent years (Fig. 1f).

According to tower $L$ height profile measurements in November 2001, slightly less $L$ was located in the lower canopy on the TFR plot compared to the Control, such that $65 \%$ and $71 \%$ of total $L$ occurred above $20 \mathrm{~m}$ on the Control and TFR plots respectively (Fig. 3d). 


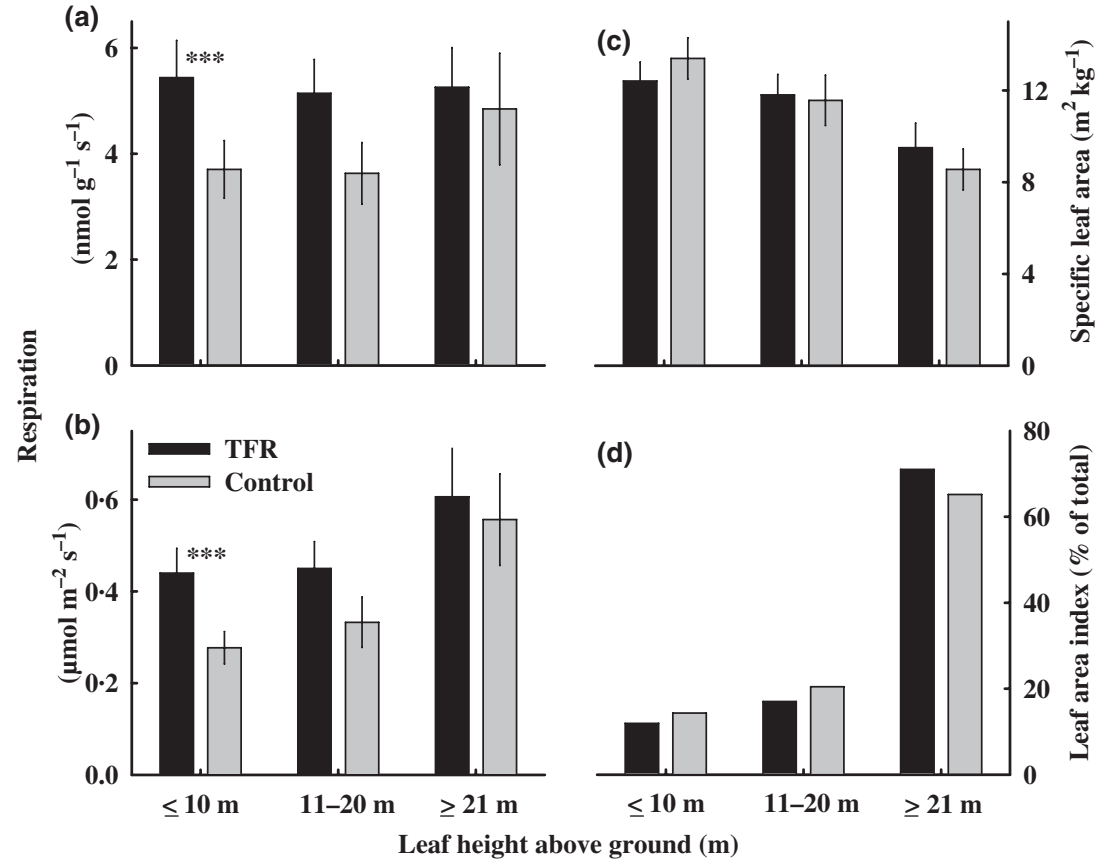

Fig. 2. Plot differences in respiration per unit mass (a) and area (b), specific leaf area (c) and leaf area index (d) amongst canopy height categories $(\leq 10, \quad 11-20, \geq 21 \mathrm{~m})$. TFR, through-fall reduction. Values denote plot means $\pm 95 \%$ confidence intervals from data pooled across all post-treatment sampling sessions, with the exception of the $L$ canopy profile which was measured only once, before the drought treatment in November 2001. ${ }^{* * *}$ Significant plot differences $(P<0.001)$.

\section{PLOT TREND IN FOLIAGE MASS}

On both plots over all measurement campaigns, $M$ varied between 4 and $5.5 \mathrm{t} \mathrm{ha}^{-1}$ (Fig. 1g). There was no clear difference in $M$ between the plots over the first few years of the TFR treatment, because lower TFR plot $L$ (Fig. 1f) was offset by higher $S$ (Fig. 1e) compared to the Control. This changed by the last measurement campaign (January 2007) when the TFR plot $S$ fell back to levels similar to that of the Control, but $L$ remained relatively low, with the consequence that estimated $M$ was $1 \cdot 2 \pm 0.7$ lower on the TFR plot compared to the Control (Fig. 1e-g).

\section{Discussion}

ESTIMATING STAND-SCALE NIGHT-TIME FOLIAR CARBON EFFLUX

Combining leaf-level $R$ and $S$ data with $L$, to produce estimates of stand-scale foliar respiration, illustrates how their individual responses interact to determine ecosystem foliar $\mathrm{C}$ emissions, and how this differs between plots. The results indicate that the effect of the decline in the amount of respiring leaf tissue in the TFR plot, measured as $L$, was outweighed by the simultaneous increase in $R$ per unit area. The estimated net consequence of these opposing changes was that night-time foliar $\mathrm{C}$ emissions from the TFR plot increased by $1.4 \pm 1.2,0.7 \pm 0.4$ and $1.8 \pm 0.9 \mathrm{t} \mathrm{ha}^{-1}$ year $^{-1}$ compared to the Control in the last three measurement campaigns $1.4,1.9$ and $5 \cdot 1$ years after imposition of the TFR treatment respectively (Table 3 ). The three previous measurements (before, 0.4 and 0.9 years after the TFR treatment) showed no clear difference in night-time foliar $\mathrm{C}$ emissions between plots (Table 3). By comparison, the largest single ecosystem respiration term - soil $\mathrm{CO}_{2}$ efflux - was estimated to be 4.2 and $0.7 \mathrm{t} \mathrm{C} \mathrm{ha}^{-1}$ year $^{-1}$ lower on the TFR plot relative to the Control in 2003 (Sotta et al. 2007) and 2006 (Metcalfe et al. 2007) respectively. Thus, incorporating the plot differences in night-time foliar $\mathrm{C}$ emissions estimated in this study offsets a large portion of the estimated droughtinduced reduction in soil $\mathrm{CO}_{2}$ efflux. Given that atmospheric $\mathrm{CO}_{2}$ fertilization of Amazon vegetation is unlikely to stimulate net ecosystem uptake far in excess of $0.5 \mathrm{t} \mathrm{C} \mathrm{ha}^{-1}$ year $^{-1}$ (Phillips et al. 1998; Chambers et al. 2001, 2004a; Baker et al. 2004) we suggest that inclusion, and improved quantification, of night-time foliar $\mathrm{C}$ emissions in atmosphere-biosphere models could be vital for accurate prediction of changes in Amazon forest $\mathrm{C}$ exchange in response to climate change.

The approach taken in this study to up-scaling leaf-level $R$ measurements makes a number of assumptions which deserve examination. First, it is unclear how confidently $R$ measured during the day (albeit equilibrated to dark conditions) may be extrapolated to night-time conditions (Hubbard, Ryan \& Lukens 1995), although at a similar Amazon rain forest type to our study site, $R$ measured from 27 trees showed no clear diurnal variation in $R$, and no significant difference between night- and day-time values (Chambers et al. 2009). Secondly, our assumption of constant temperature $\left(25^{\circ} \mathrm{C}\right)$ on both plots and $12 \mathrm{~h}$ of darkness each day throughout the year is clearly simplistic though any error introduced is minor compared to natural intra- and inter-species variation, and affects both plots similarly. Thus, this method facilitates direct comparison of plots and, in the absence of more detailed process-level data, provides a transparent basis for up-scaling instantaneous measurements.

\section{DROUGHTEFFECTS ON LEAF RESPIRATION AND MORPHOLOGY}

Estimates of $R$ from this study are consistent with previous estimates from other lowland Amazon rain forest ecosystems 
(Table 4). While there were significant differences in $R$ between the plots after several years of the TFR treatment, these differences were relatively minor compared to global variation amongst studies, sites and biomes (Wright et al. 2006). In this study, evidence for enhancement of $R$ by drought comes from (i) the increase in $R$ over time since imposition of the TFR treatment, (ii) the higher mean $R$ compared to the Control during each individual measurement campaign and (iii) the slight but consistent increase in $R$ on both plots during the dry seasons (Fig. 1, Table 5). While only some of these differences were statistically significant individually, the effect was consistent across all post-treatment measurement campaigns. Leaf nitrogen content did not differ between plots, neither was there a clear correlation between leaf nitrogen content and $R$ (R. Lobo-do-Vale, unpublished data). Other studies in the Amazon have also recorded an increase in $R$ in the dry season compared to the wet season (Table 4). In addition, a comprehensive survey across 208 woody plant species from 20, mainly temperate, sites showed that, for a given $S, R$ was higher at low-rainfall sites compared to higher rainfall sites (Wright et al. 2006; but see Flexas et al. 2005; Atkin \& Macherel 2008). The change in $R$ in all these studies could either reflect a shift in $R$ for a given $S$, or altered $S$ with little concomitant change in $R$, or some combination of these two processes. Potential mechanisms for enhanced $R$ at a given $S$ under moisture stress include: increased energy demand for the maintenance of vacuolar solute gradients, repair of water-stress-induced cell damage and/or increased wastage respiration via futile cycles (Hue 1982; Lambers 1997; Lambers, Chapin \& Pons 1998; Cannell \& Thornley 2000; Flexas et al. 2005; Würth et al. 2005; Wright et al. 2006; Atkin \& Macherel 2009). Determining which of these processes dominate will be important for modelling the pattern and magnitude of change in $R$ across the Amazon in the face of future climate changes.

The reduction in $L$ on the TFR plot (Fig. 1f) was consistent with existing data on Amazon forest responses to soil moisture deficit (Nepstad et al. 2002; Fisher et al. 2007; Myneni et al. 2007) and over the first 3 years of the TFR treatment was largely caused by declining $S$, because total plot $M$ remained remarkably similar between the plots despite substantial seasonal variation (Fig. 1g). In January 2007, lower $L$ on the TFR plot could not be attributed to $S$ and was therefore most likely a product of an imbalance between leaf growth and shedding (Fig. 1g). Changes in $S$ may reflect adaptation to drought on the part of TFR plot trees by developing thicker and/or denser leaves (Witkowski \& Lamont 1991). The abrupt drop in $L$ during November 2002 followed by a sharp rise in $M$ (Fig. 1f,g) on both plots was also attributable to a decline in $S$. The reason for this change is not known. The meteorological conditions during this period do not appear to have been anomalous while the equipment and sampling strategy used to quantify $L$ and $S$ remained the same over this period. Taken together this suggests that the decline in $L$ and $S$ over this period was a real biological pattern perhaps linked to seasonal phenology rather than an artefact of methodology.
The pattern of change in $R$ through the canopy was strikingly different between plots: with significantly higher rates of $R$ (Fig. 2a,b) in foliage below $20 \mathrm{~m}$ on the TFR plot compared to the Control. It is unlikely that the infrastructure of the TFR plot itself could account for these differences because the panels diverting rainfall were installed to a maximum height of $2 \mathrm{~m}$, while all $R$ measurements were recorded in tree canopies above this height. We suggest that the plot differences in the pattern of change in $R$ through the canopy more likely reflect the fact that most of the lower leaves sampled came from smaller stature trees with shallower root systems, which were likely to suffer more from surface soil moisture limitation.

\section{Conclusion}

This study evaluated the drought sensitivity of $R$ at an eastern Amazon rain forest site. Partial rainfall exclusion of a 1-ha area of rain forest was associated with an estimated increase in night-time foliar $\mathrm{C}$ emissions of $1.4,0.7$ and $1.8 \mathrm{t}$ $\mathrm{ha}^{-1}$ year $^{-1}$ compared to forest on a nearby Control plot $1.4,1.9$ and 5.1 years after rainfall exclusion respectively. This drought-induced physiological shift, if shown to occur more widely, might be sufficient to offset current estimates of the Amazon forest $\mathrm{C}$ sink, and alter model predictions of future changes in net $\mathrm{C}$ emissions from the Amazon basin. To build upon the key conclusions of this study more measurements are required to improve our understanding of the spatial and temporal variation in $R$, and of leaf respiration under light conditions.

\section{Acknowledgements}

This research contributes to the Brazil-led Large Scale Biosphere-Atmosphere Experiment in Amazonia. Fieldwork was supported by an Edinburgh University Small Project Grant. The authors thank Leonardo Sá and Ima Vieira for their scientific support and collaboration, and the Museu Paraense Emilio Goeldi for the use of its field station and laboratory facilities.

\section{References}

Aragão, L.E.O.C., Shimabukuro, Y.E., Espírito Santo, F.D.B. \& Williams, M. (2005) Landscape pattern and spatial variability of leaf area index in Eastern Amazonia. Forest Ecology and Management, 211, 240-256.

Atkin, O.K., Bruhn, D. \& Tjoelker, M.G. (2005) Response of plant respiration to changes in temperature: mechanisms and consequences of variations in $\mathrm{Q}_{10}$ values and acclimation. Plant Respiration: From Cell to Ecosystem (eds H. Lambers \& M. Ribas-Carbó), pp. 95-135. Springer, The Netherlands.

Atkin, O.K., Evans, J.R. \& Siebke, K. (1998) Relationship between the inhibition of leaf respiration by light and enhancement of leaf dark respiration following light treatment. Australian Journal of Plant Physiology, 25, 437-443.

Atkin, O.K. \& Macherel, D. (2009) The crucial role of plant mitochondria in orchestrating drought tolerance. Annals of Botany, 103, 581-597.

Atkin, O.K. \& Tjoelker, M.G. (2003) Thermal acclimation and the dynamic response of plant respiration to temperature. Trends in Plant Science, 8, 343351 .

Baker, T.R., Phillips, O.L., Malhi, Y., Almeida, S., Arroyo, L., Di Fiore, A., Erwin, T., Higuchi, N., Killeen, T.J., Laurance, S.G., Laurance, W.F., Lewis, S.L., Monteagudo, A., Neill, D.A., Nunez Vargas, P., Pitman, N.C.A., Silva, J.N.M. \& Vasquez Martinez, R. (2004) Increasing biomass in Amazonian forest plots. Philosophical Transactions of the Royal Society of London-Biological Sciences, 359, 353-356. 
Brando, P.M., Nepstad, D.C., Davidson, E.A., Trumbore, S.E., Ray, D. \& Camargo, P. (2008) Drought effects on litterfall, wood production, and belowground carbon cycling in an Amazon forest: results of a through-fall reduction experiment. Philosophical Transactions of the Royal Society of London-Biological Sciences, 363, 1839-1848.

Cannell, M.G.R. \& Thornley, J.H.M. (2000) Modelling the components of plant respiration: some guiding principles. Annals of Botany, 85, 45-54.

Carpenter, S.R. (1996) Microcosm experiments have limited relevance for community and ecosystem ecology. Ecology, 77, 677-680.

Cavaleri, M.A., Oberhauer, S.F. \& Ryan, M.G. (2008) Foliar and ecosystem respiration in an old-growth tropical rainforest. Plant, Cell and Environment, 31, 473-483.

Chambers, J.Q., Higuchi, N., Tribuzy, E.S. \& Trumbore, S.E. (2001) Carbon sink for a century. Nature, $\mathbf{4 1 0}, 429$.

Chambers, J.Q., Higuchi, N., Teixeira, L.M., Dos Santos, J., Laurance, S.G. \& Trumbore, S.E. (2004a) Response of tree biomass and wood litter to disturbance. Oecologia, 141, 596-614.

Chambers, J.Q., Tribuzy, E.S., Toledo, L.C., Crispim, B.F., Higuchi, N., Dos Santos, J., Araújo, A.C., Kruijt, B., Nobre, A.D. \& Trumbore, S.E. (2004b) Respiration from a tropical forest ecosystem: partitioning of sources and low carbon use efficiency. Ecological Applications, 14, $72-88$.

Chambers, J.Q., Tribuzy, E.S., Toledo, L.C., Crispim, B.F., Higuchi, N., Dos Santos, J., Araújo, A.C., Kruijt, B., Nobre, A.D. \& Trumbore, S.E. (2009) Tropical forest ecosystem respiration, Manaus, Brazil. Dataset available online (http://daac.ornl.gov) from Oak Ridge National Laboratory Distributed Active Archive Center, Oak Ridge, Tennessee, USA. DOI: 10.3334/ ORNLDAAC/912.

Chaves, M.M. \& Oliveira, M.M. (2004) Mechanisms underlying plant resilience to water deficits: prospects for water-saving agriculture. Journal of Experimental Botany, 55, 2365-2384.

Christensen, J.H., Hewitson, B., Busuioc, A., Chen, A., Gao, X., Held, I., Jones, R., Kolli, R.K., Kwon, W.T., Laprise, R., Magaña Rueda, V., Mearns, L., Menéndez, C.G., Räisänen, J., Rinke, A., Sarr, A. \& Whetton, P. (2007) Regional climate projections. Climate Change 2007: The Physical Science Basis. Contribution of Working Group I to the Fourth Assessment Report of the Intergovernmental Panel on Climate Change (eds S. Solomon, D. Qin, M. Manning, Z. Chen, M. Marquis, K.B. Averyt, M. Tignor \& H.L. Miller), pp. 847-940. Cambridge University Press, Cambridge, UK

Cox, P.M., Betts, R.A., Jones, C.D., Spall, S.A. \& Totterdell, I.J. (2000) Acceleration of global warming due to carbon cycle feedbacks in a coupled climate model. Nature, 408, 184-187.

Cox, P.M., Harris, P.P., Huntingford, C., Betts, R.A., Collins, M., Jones, C.D., Jupp, T.E., Marengo, J.A. \& Nobre, C.A. (2008) Increasing risk of Amazonian drought due to decreasing aerosol pollution. Nature, 453, 212-216.

Davidson, E.A., Ishida, F.Y. \& Nepstad, D.C. (2004) Effects of an experimental drought on soil emissions of carbon dioxide, methane, nitrous oxide, and nitric oxide in a moist tropical forest. Global Change Biology, 10, 718-730

Davidson, E.A., Verchot, L.V., Cattânio, J.H., Ackerman, I.L. \& Carvalho, J.E.M. (2000) Effects of soil water content on soil respiration in forests and cattle pastures of eastern Amazonia. Biogeochemistry, 48, 53-69.

Domingues, T.F., Berry, J.A., Martinelli, L.A., Ometto, J.P.H.B. \& Ehleringer, J.R. (2005) Parameterizations of canopy structure and leaf-level gas exchange for an eastern Amazonian tropical rain forest (Tapajós National Forest, Pará, Brazil). Earth Interactions, 9, 1-23.

Fisher, R.A., Williams, M., Lola Da Costa, A., Malhi, Y., Da Costa, R.F., Almeida, S. \& Meir, P. (2007) The response of an eastern Amazonian rain forest to drought stress: results and modeling analyses from a throughfall exclusion experiment. Global Change Biology, 13, 2361-2378.

Flexas, J., Bota, J., Loreto, F., Cornic, G. \& Sharkey, T.D. (2004) Diffusive and metabolic limitations to photosynthesis under drought and salinity in $\mathrm{C}_{3}$ plants. Plant Biology, 6, 269-279.

Flexas, J., Galmes, J., Ribas- Carbó, M. \& Medrano, H. (2005) The effects of water stress on plant respiration. Plant Respiration: From Cell to Ecosystem (eds H. Lambers \& M. Ribas-Carbó), pp. 95-135. Springer, The Netherlands.

Gotelli, N.J. \& Ellison, A.M. (2004) A primer of ecological statistics. Sinauer Associates, , Sunderland, MA, U.S.A.

Hanson, P.J. \& Wullschleger, S.D. (2003) North American temperate deciduous forest responses to changing precipitation regimes. Springer-Verlag, New York, NY, U.S.A.

Harris, P.P., Huntingford, C. \& Cox, P.M. (2008) Amazon Basin climate under global warming: the role of the sea-surface temperature. Philosophical Transactions of the Royal Society of London B, 363, 1753-1759.
Hubbard, R.M., Ryan, M.G. \& Lukens, D.L. (1995) A simple, battery-operated, temperature-controlled cuvette for respiration measurements. Tree Physiology, 15, 175-179.

Hue, L. (1982) Futile cycles and regulation of metabolism. Metabolic compartmentation (ed H. Sies), pp. 71-97. Academic Press, Burlington, MA, U.S.A.

Hurlbert, S.H. (1984) Pseudoreplication and the design of ecological field experiments. Ecological Monographs, 54, 187-211.

Hurlbert, S.H. (2004) On misinterpretations of pseudoreplication and related matters: a reply to Oksanen. Oikos, 104, 591-597.

Hutyra, L.R., Munger, J.W., Saleska, S.R., Gottlieb, E., Daube, B.C., Dunn, A.L., De Camargo, P.B. \& Wofsy, S.C. (2007) Seasonal controls on the exchange of carbon and water in an Amazonian rain forest. Journal of Geophysical Research - Biogeosciences, 112, G03008. DOI: 10.1029/ 2006JG000365.

Lambers, H. (1997) Respiration and the alternative oxidase. A molecular approach to primary metabolism in plants (eds C.H. Foyer \& W.P. Quick). pp. 295-309, Taylor \& Francis, London, U.K.

Lambers, H., Chapin III, F.S. \& Pons, T.L. (1998) Plant physiological ecology. Springer-Verlag, New York, NY, U.S.A.

Malhi, Y., Baldocchi, D.D. \& Jarvis, P.G. (1999) The carbon balance of tropical, temperate and boreal forests. Plant, Cell and Environment, 22, 715-740.

Malhi, Y., Roberts, J.T., Betts, R.A., Killeen, T.J., Li, W. \& Nobre, C.A. (2008) Climate change, deforestation and the fate of the Amazon. Science, 319, 169-172.

McCree, K.J. (1970) An equation for the rate of respiration of white clover plants under controlled conditions. Prediction and Measurement of Photosynthetic Productivity (ed. I. Setlik), pp. 221-229. Pudoc, The Netherlands.

Meir, P., Grace, J. \& Miranda, A.C. (2001) Leaf respiration in two tropical rainforests: constraints on physiology by phosphorus, nitrogen and temperature. Functional Ecology, 15, 378-387.

Meir, P., Metcalfe, D.B., Costa, A.C.L. \& Fisher, R.A. (2008) The fate of assimilated carbon during drought: impacts on respiration in Amazon rainforests. Philosophical Transactions of the Royal Society-Biological Sciences, 363, 1849-1855.

Metcalfe, D.B., Meir, P., Aragão, L.E.O.C., Malhi, Y., Da Costa, A.C.L., Braga, A., Gonçalves, P.H.L., De Athaydes, J., De Almeida, S.S. \& Williams, M. (2007) Factors controlling spatio-temporal variation in carbon dioxide efflux from surface litter, roots, and soil organic matter at four rain forest sites in the eastern Amazon. Journal of Geophysical Research-Biogeosciences, 112, G04001. DOI: 10.1029/2007JG000443.

Miranda, E.J., Vourlitis, G.L., Filho, N.P., Priante, P.C., Campelo, J.H., Jr, Suli, G.S., Fritzen, C.L., De Almeida Lobo, F. \& Shiraiwa, S. (2005) Seasonal variation in the leaf gas exchange of tropical forest trees in the rain forest-savanna transition of the southern Amazon basin. Journal of Tropical Ecology, 21, 451-460.

Mood, A.M., Graybill, F.A. \& Boes, D.C. (1974) Introduction to the theory of statistics. The Mcrraw-Hill Companies, Columbus, OH, U.S.A.

Myneni, R.B., Yang, Y., Ramakrishna, R.N., Huete, A.R., Dickinson, R.E., Knyazikhin, Y., Didan, K., Fu, R., Negrón Juárez, R.I., Saatchi, S.S., Hashimoto, H., Ichii, K., Shabanov, N.V., Tan, B., Ratana, P., Privette, J.L., Morisette, J.T., Vermote, E.F., Roy, D.P., Wolfe, R.E., Friedl, M.A., Running, S.W., Votava, P., El-Saleous, N., Devadiga, S., Su, Y. \& Salomonson, V.V. (2007) Large seasonal swings in leaf area of Amazon rainforests. Proceedings of the National Academy of Sciences, USA, 104, 4820-4823.

Nepstad, D.C, Moutinho, P., Dias-Filho, M.B., Davidson, E., Cardinot, G., Markewitz, D., Figueiredo, R., Vianna, N., Chambers, J., Ray, D., Guerreiros, J.B., Lefebvre, P., Sternberg, L., Moreira, M., Barros, L, Ishida, F.Y., Tohlver, I., Belk, E., Kalif, K. \& Schwalbe, K. (2002) The effects of partial throughfall exclusion on canopy processes, aboveground production and biogeochemistry of an Amazon forest. Journal of Geophysical Research 107, D20, 8085, DOI: 10.1029/2001JD000360.

Osmond, B., Ananyev, G., Berry, J., Langdon, C., Kolber, Z., Lin, G.H., Monson, R., Nichol, C., Rascher, U., Schurr, U., Smith, S. \& Yakir, D. (2004) Changing the way we think about global change research: scaling up in experimental ecosystem science. Global Change Biology, 10, 393-407.

Peylin, P., Bousquet, P., Le Quéré, C., Sitch, S., Friedlingstein, P., McKinley, G., Gruber, N., Rayner, P. \& Ciais, P. (2005) Multiple constraints on regional $\mathrm{CO}_{2}$ flux variations over land and oceans. Global Biogeochemical Cycles, 19, GB1011. DOI: 10.1029/2003GB002214.

Phillips, O.L., Malhi, Y., Higuchi, N., Laurance, W.F., Nuñez Vargas, P., Vásquez Martinez, R., Laurance, S.G., Ferriera, L.V., Stern, M., Brown, S. \& Grace, J. (1998) Changes in the carbon balance of tropical forests: evidence from long-term plots. Science, 282, 439-442. 
Pons, T.L. \& Welschen, R.A.M. (2002) Overestimation of respiration rates in commercially available clamp-on leaf chambers. Complications with measurement of net photosynthesis. Plant, Cell and Environment, 25, 1367-1372.

Rasmussen, P.W., Heisey, D.M., Nordheim, E.V. \& Frost, T.M. (2001) Time series intervention analysis: unreplicated large-scale experiments. Design and analysis of ecological experiments (eds S.M. Scheiner \& J. Gurevitch), Oxford University Press, Oxford, U.K.

Reich, P.B., Walters, M.B., Ellsworth, D.S., Vose, J.M., Volin, J.C., Gresham, C. \& Bowman, W.D. (1998) Relationships of leaf dark respiration to leaf nitrogen, specific leaf area and leaf life-span: a test across biomes and functional groups. Oecologia, 114, 471-482.

Roedenbeck, C., Howling, S., Gloor, M. \& Heimann, M. (2003) $\mathrm{CO}_{2}$ flux history 1982-2001 inferred from atmospheric data using a global inversion of atmospheric transport. Atmospheric Chemistry and Physics, 3, 1914-1964.

Saleska, S.R., Miller, S.D., Matross, D.M., Goulden, M.L., Wofsy, S.C., Da Rocha, H.R., De Camargo, P.B., Crill, P., Daube, B.C., De Freitas, H.C., Hutyra, L., Keller, M., Kirchhoff, V., Menton, M., Munger, J.W., Pyle, E.H., Rice, A.H. \& Silva, H. (2003) Carbon in Amazon forests: unexpected seasonal fluxes and disturbance-induced losses. Science, 302, 1554-1557.

Santiago, L.S. \& Mulkey, S.S. (2003) A test of gas exchange measurements on excised canopy branches of ten tropical tree species. Photosynthetica, 41, 343-347.

Schwendenmann, L., Veldkamp, E., Brenes, T., O’Brien, J.J. \& Mackensen, J (2003) Spatial and temporal variation in soil $\mathrm{CO}_{2}$ efflux in an old-growth neotropical rain forest, La Selva, Costa Rica. Biogeochemistry, 64, 111-128.

Sotta, E.D., Meir, P., Malhi, Y., Nobre, A.D., Hodnett, M. \& Grace, J. (2004) Soil $\mathrm{CO}_{2}$ efflux in a tropical forest in the central Amazon. Global Change Biology, 10, 601-617.

Sotta, E.D., Veldkamp, E., Schwendenmann, L., Guimarães, B.R., Paixão, R.K., Ruivo, M.L.P., Da Costa, A.C.L. \& Meir, P. (2007) Effects of an induced drought on soil carbon dioxide $\left(\mathrm{CO}_{2}\right)$ efflux and soil $\mathrm{CO}_{2}$ production in an eastern Amazonian rainforest, Brazil. Global Change Biology, 13, 2218-2229.
Stokstad, E. (2005) Experimental drought predicts grim future for rainforest. Science, 308, 346-347.

Sullivan, T.J. (1997) Ecosystem manipulation experimentation as a means of testing a biogeochemical model. Environmental Management, 21, 1521.

Tian, H., Melillo, J.M., Kicklighter, D.W., McGuire, A.D., Helfrich, J.V.K., III, Moore, B., III \& Vörösmarty, C.J. (1998) Effect of interannual variability on carbon storage in Amazonian ecosystems. Nature, 396, 664-667.

Underwood, A.J. (1997) Experiments in ecology: their logical design and interpretation using analysis of variance. Cambridge University Press, Cambridge, U.K.

Vourlitis, G.L., De Souza Nogueira, J., Filho, N.P., Hoeger, W., Raiter, F., Biudes, M.S., Arruda, J.C., Capistrano, V.B., De Faria, J.L.B. \& De Almeida Lobo, F. (2005) The sensitivity of diel $\mathrm{CO}_{2}$ and $\mathrm{H}_{2} \mathrm{O}$ vapor exchange of a tropical transitional forest to seasonal variation in meteorology and water availability. Earth Interactions, 9, 1-23.

Werth, D. \& Avissar, R. (2002) The local and global effects of Amazon deforestation. Journal of Geophysical Research, 107, D20. DOI: 10.1029/ 2001JD000717.

Witkowski, E.T.F. \& Lamont, B.B. (1991) Leaf specific mass confounds leaf density and thickness. Oecologia, 88, 486-493.

Wright, I.J., Reich, P.B., Atkin, O.K., Lusk, C.H., Tjoelker, M.G. \& Westoby, M. (2006) Irradiance, temperature and rainfall influence leaf dark respiration in woody plants: evidence from comparisons across 20 sites. New Phytologist, 169, 309-319.

Würth, M.K.R., Pelaez-Riedl, S., Wright, S.J. \& Körner, C. (2005) Non-structural carbohydrate pools in a tropical forest. Oecologia, 143, 11-24.

Zeng, N., Mariotti, A. \& Wetzel, P. (2005) Terrestrial mechanisms of interannual $\mathrm{CO}_{2}$ variability. Global Biogeochemical Cycles, 19, GB1016. DOI: 10.1029/2004GB002273.

Received 6 July 2009; accepted 14 December 2009

Handling Editor: David Whitehead 